\title{
KAIST における複合材料の研究活動
}

\author{
Chun-Gon Kim*1 (翻訳 輔章*2)
}

KAIST (Korean Advanced Institute of Science and Technology；韓国大田）には複合材料の研究活動をして いる研究室は複数存在する。これらの研究室の中で下記 の 4 研究室の研究活動をこの解説記事で紹介する.

・スマート構造・複合材料研究室: 航空宇宙工学校

・知的システム・振動制御研究室: 航空宇宙工学校

・先進材料を用いた機械設計研究室：機械工学校

- 複合材料研究室：材料科学・工学科

\section{1. スマート構造・複合材料研究室}

スマート構造・複合材料研究室 (http://smartech.ac. kr) は 1979 年に設立され 2 名の教授 (C.S. Hong 教授と C.G. Kim 教授)が着任し, 20 名以上の修士と博士の学生 が所属している. 研究は複合材料構造の解析, 設計, 製 作, 光ファイバーセンサー構造, 損傷検知, 構造ヘルス モニタリングなどが行われている.これらの技術は航空 宇宙の設計製作で次第に適用されている.これらのいく つかの研究について簡単に解説する。

\section{1 光ファイバーセンサーを用いたひずみや破壊の} 同時計測（図 1 参照）

稼動条件下での複合材料構造の安全性や信頼性を確認 するために，稼動中の構造モニタリングのための新しい 非破壊検査 (NDI) 手法を確立することが望まれている. この研究の目的は光ファイバーセンサーを用いた複合材 料のリアルタイムの破壊信号やひずみの測定手法を開発 することである。この研究において, 広帯域 FBG(ファ イバーブラッググレーティング : Fiber Bragg Grating) 反射鏡を用いた同時センシング技術を当研究室では提案 している.引張試験の結果から, AEFPI センサー(Absolute Extrinsic Fabry-Perot Interferometer) で測定した ひずみは電気抵抗線ひずみゲージの測定結果と良く一致

*1 韓国科学技術院航空宇宙工学校

373-1 Kusong-dong, Yusong-gu, Taejon 305-701, Korea

*2 Akira TODOROKI : 東京工業大学大学院理工学研究 科機械物理工学専攻(152-8552 東京都目黑区大岡山 $2-12-1)$
し，マイクロクラックの信号を検出することで破壊検知 することが可能であることが示された.

1.2 偏光維持ファイバーを用いた FBG センサーの 信号特性 (図 2 参照)

ほとんどの光ファイバーひずみセンサーはファイバー の緘維方位ひずみ成分しか測定できない，この研究で は, 直交方位の 2 方位のひずみを測定可能な光ファイバ 一センサーが研究されている。そのセンサーは 1 本の 2 つの屈折率を持つ偏光維持光ブラッググレーティングフ アイバーセンサーである. 光ファイバーコア中の 2 つの 独立した直交ひずみ成分は，2つのピーク值の波長変化 から計算される。ブラッググレーティングを使うことの 利点はひずみ情報がセンサーから反射される光の周波数 変化にコーディングされることであり，これによって簡 単に多重化が可能となる可能性を有している.

\section{$1.3 \mathrm{C} / \mathrm{C}$ 複合材ブレーキディスクの解析と設計 (図 3} 参照)

$\mathrm{C} / \mathrm{C}$ は高温環境での優れた特性から, 航空機のブレー キシステムで特に使われている.この研究の目的は航空 機に使用されている $\mathrm{C} / \mathrm{C}$ 複合材のブレーキディスクシ ステムのための実験的・解析的設計手法の開発である. この研究の最終目標は, $\mathrm{C} / \mathrm{C}$ 複合材の機械的特性を評価 し, ブレーキシステムの過渡的な温度・応力場の熱弾性 解析の検討とブレーキシステムの破壊解析によって, よ り安全で効率的なブレーキシステムを開発することであ る.

\section{4 空間的に強化された複合材製ノズルの熱弾性解 析 (図 4 参照)}

$\mathrm{C} / \mathrm{C}$ で空間的に強化された複合材製キックモーター ノズル (SRC) の)熱的・機械的特性を予測し, 有限要素 解析からノズルの熱弾性挙動を解析している.この解析 結果から, SRC の横方向熱伝導が軸方向よりもノド部の 温度分布に大きな影響を及ほすすことが明らかになった。 また, 他の部分よりも $\mathrm{C} / \mathrm{C}$ 複合材 $\mathrm{SRC}$ と $\mathrm{C} /$ フェノール の境界に抢いて温度勾配が急であることがわかった。

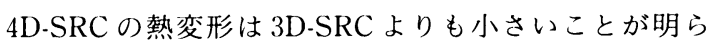
かになった。しかし, 応力分布は類似していた。 


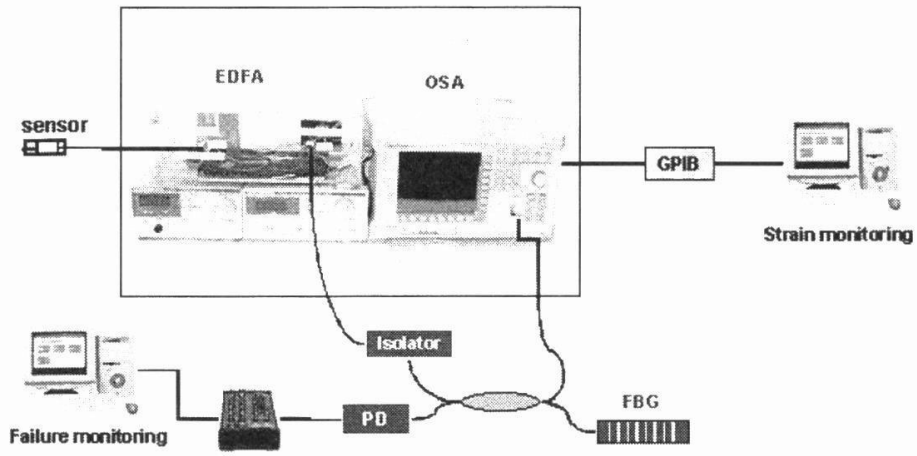

図 1 リアルタイムひずみ測定・破壊モニタリング用光ファイバーセンサーシステム概念図

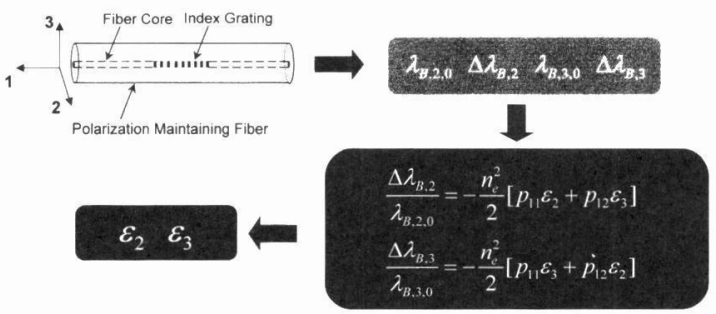

図 2 開発したFBGシステムによるひずみ測定原理

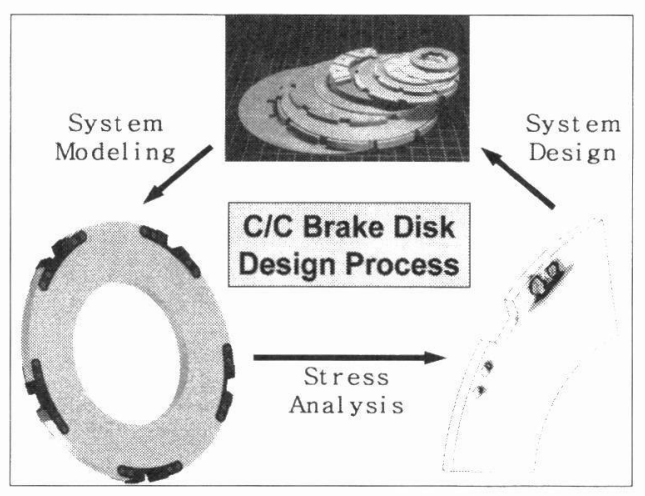

㘠 $3 \mathrm{C} / \mathrm{C}$ 複合材ブレーキディスク

\section{5 フィラメントワインディング圧カタンクの解析 と設計（図 5 参照)}

金属燃料タンクに比較して，フィラメントワインディ ング (FW) 圧力タンクは剛性や耐熱性に優れた特性を 有している。それにもかかわらず，FW 成形の適用は谷 易ではない. FW 圧力タンクは長軸方位に沿った鏡部に おいて複雑な特性と形状を有している．FW 構造の举動 を理解するためや複合材圧力タンクの設計には洗練され た解析手法が必要である.この研究では, ABAQUS 解析 の便利のためにプリプロセッサ (PreAft) が開発された。

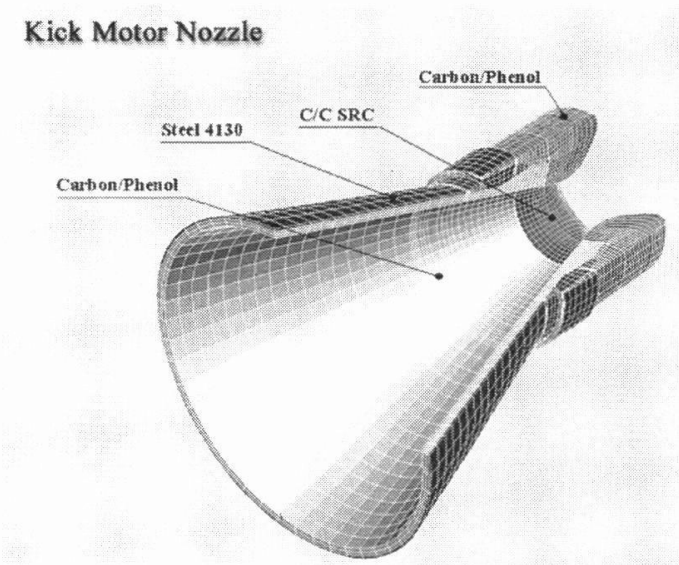

闵 4 キックモーターノズル

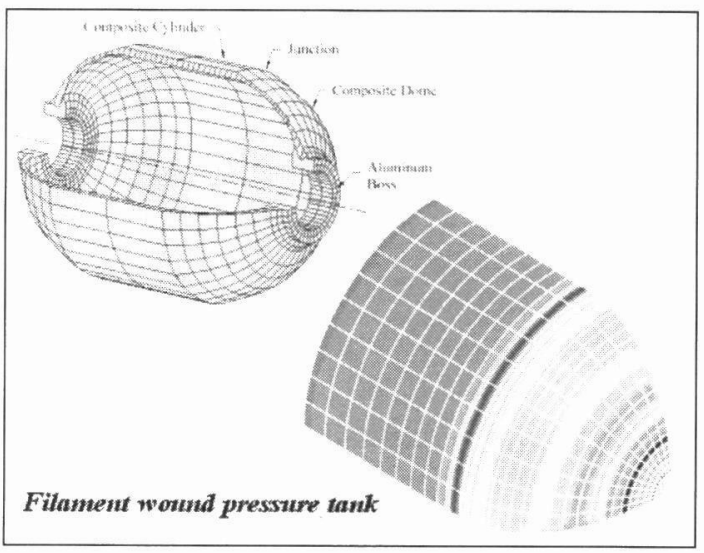

図 5 FW 圧力タンク

PreAft は FW 圧力タンクの非線形解析のために ABA. QUS 用の入力ファイルを作成し, ABAQUSを用いた非 線形有限要素解析からスペック（体積, 重量, など）に 


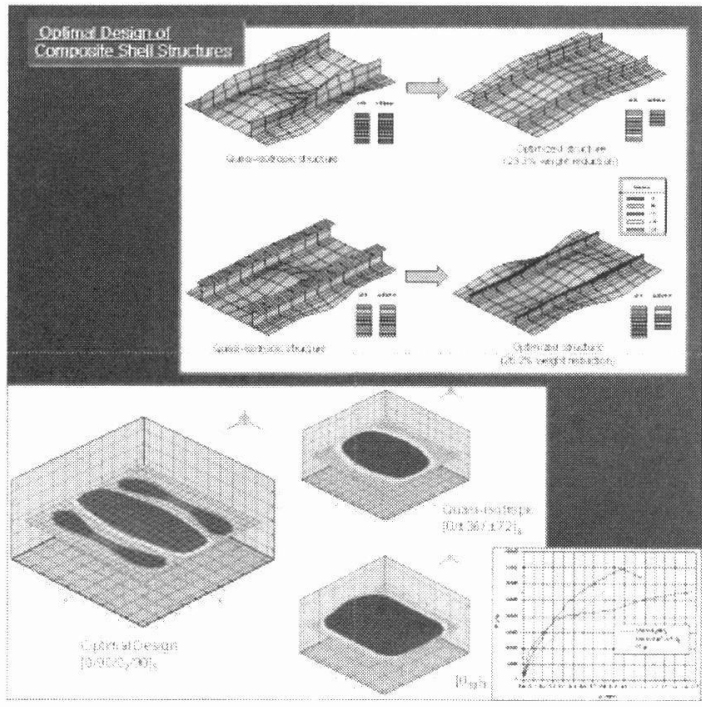

図 6 複合材シェル構造の最適設計

合致した FW 圧力タンクの最適設計を実行する.

1.6 エキスパートシステムを用いた複合材シェル構 造の最適設計（図6 参照)

複合材構造では, 繊維方位や積層構成を制御すること で設計者の目的に合致した最適な設計を実施することが できる。しかし，従来の金属材料と異なり，複合材料の 適用には多くの困難がある。例えば，強い機械的特性の 異方性のために従来と異なる解析方法を採用しなければ ならないこと, 複雑な層間相互作用, 設計経験の不足な どである.これらの経験のない設計者には, エキスパー トシステムの導入が有効である。さらに，実際に使用さ れている複合材料の積層繊維方位は連続変数ではなく離 散的であるために, 離散的な最適設計が必要である。こ れらの背景から,この研究の主要な目槽は, 複合材積層 構造の予備設計や最適設計のための工キスパートシステ ムの統合と離散的な最適設計法の開発である.

\section{7 光ファイバーセンサーを用いた宇宙環境での複} 合材料の熱膨張率変化の測定（図 7 参照)

近年, 宁宙構造物に複合材料は頻繁に使用されるよう になってきた。宇宙環境下での複合材料の熱膨張係数変 化の研究のために, 光ファイバーセンサーを CF/エポキ シ複合材 (HFG CU-125 NS) に埋め込んだ。この複合材 を, 低軌道を模擬した高真空 $\left(10^{-5} \sim 10^{-6}\right.$ Terr $)$ で紫外 線照射 $\left(200 \mathrm{~nm}\right.$ 以下) の熱サイクル $\left(-80^{\circ} \mathrm{C} \sim 100^{\circ} \mathrm{C}\right)$ 環 境の熱真空炉に設置して環境負荷を与えた。

光ファイバーセンサーは多くの利点を有している.

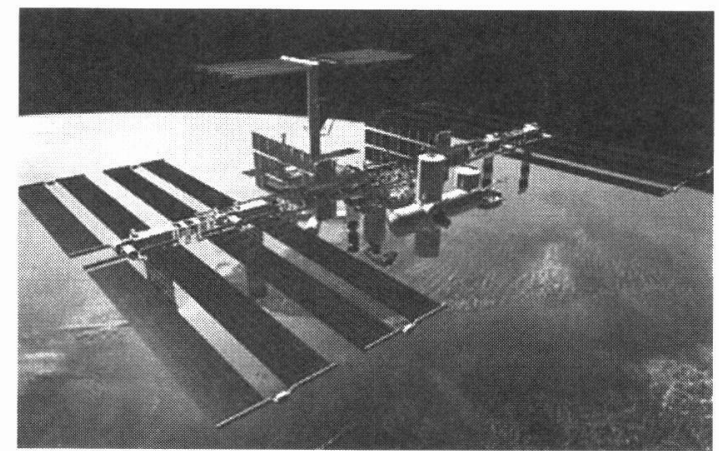

図 7 宇宙ステーション

EMI 特性, 広い温度範囲, 省スペース, 軽量などである. このため，過酷な宇宙環境では光ファイバーセンサーは 宇宙構造に非常に適している。この研究では, ひずみと 温度を同時に測定するために FBG センサーが使用され ている。この研究によって, 宇宙構造のへルスモニタリ ングが可能となる。

\section{2. 知的システム・振動制御研究室}

知的システム・振動制御研究室 (http://asdl.kaist.ac. kr）は1987 年にスマート構造と空力弾性の重点的研究 のために設立された. In Lee 教授と 12 名の修士と博士 課程の学生, 1 名のポスドクが配属されており, スマート 構造, 複合材料, 航空宇宙構造の熱圧電効果, 熱弾性, 構造振動制御, 空力弾性やフラッ夕制御の研究が行われ ている，研究活動は以下の通りである.

・適応振動制御：ニューラルネット, 適応 PPF, 適応 シャントを用いた知的複合材構造

・アクティブ振動制御：最適制御と PPF 制御による 压電セラミックと光ファイバーセンサーを用いた知 的複合材構造の振動制御

・セミアクティブ振動抑制：ER ダンパや ER 流体埋 め込みの複合材構造による振動抑制

・パッシブダンパ強化：粘弾性層や圧電シャントを用 いたパッシブ振動抑制

・複合材構造の非線形ダイナミクス：圧電素子や粘弾 性 $\mathrm{ER}$ 流体層を有する複合材積層板やシェル構造の 非線形動力学解析

・ヘリコプタの空力弾性：ホバリング時や前進時の複 合材製へリコプタローターブレードのフラッタ解析 - 遷音速航空機の空力弾性 : 遷音速航空機の全機空力 解析

- 複合材航空機の空力解析：低速, 遷音速, 超音速下 


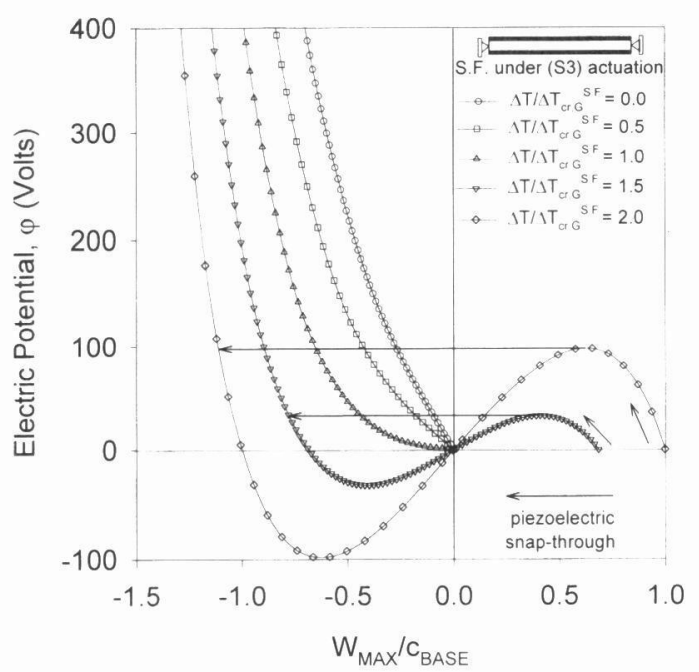

図 8 熱圧電スナップスルー現象

の複合材製航空機構造のフラッ夕解析

・パネルフラッタ：超超音速の複合材構造のフラッタ 解析

知的システム・振動制御研究室では圧電素子や粘弾性 材料, ER 流体, 光ファイバーセンサーを用いた複合材構 造の振動と変形制御の問題を研究し続けている。最近の 研究はスマート構造の変形制御である。熱や電気的な負 荷を受けた圧電素子積層板の座屈や座屈後挙動が数多く 実行されている。熱負荷による座屈後の変形制御におい て, 熱圧電スナッピング (snapping) 現象が発生する場 合がある、压電アクチュエータを使った耐熱構造の性能 向上の研究が実施されている。四8 は熱厷電スナップス ルー現象である。詳細は参考文献 AIAA Joumal, 39, 6, 1188-1197に記載されているので参照されたい.

\section{3. 先進材料を用いた機械設計研究室}

先進材料を用いた機械設計研究室 (http://lacomrs6. kaist.ac.kr, Dai Gil Lee 教授) は自動車のプロペラシャ フトや液晶ディスプレイ組み立てロボット用のエンドエ フェクタ，誘電率を用いた成形モニタリングなどの複合 材の適用製品に研究の焦点をおいている.

自動車用プロペラシャフト（図 9 参照）は前部のエン ジンから後輪駆動自動車の後部減速機まで動力を伝導し ている.プロペラシャフトは通常は曲げの固有振動数は 回転振動共振を避けるために6,500 rpmよりも大きい ことが要求され，鉄鋼材料やアルミニウム合金で作製し た 1 本のプロペラシャフトは通常は曲げの固有振動数は

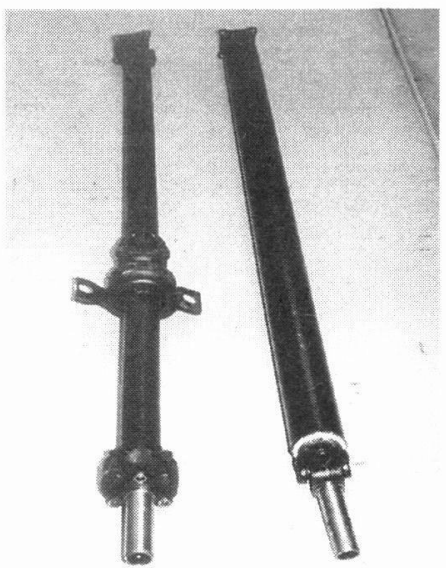

図 9 プロペラシャフト (右が鉄鋼製, 左が複合材製 $)$

この要求は達成できない.このため, 鉄鋼材料のプロペ ラシャフトは通常 2 本の接合で製造されている（図 9 参 照)。これは, 曲げ固有振動は梁の長さの 2 乗に反比例す るからである。炭素繊維複合材料の比剛性は鉄鋼材料や アルミニウム合金に比較して 4 倍程度大きいため, 炭素 繊維強化複合材料のプロペラシャフトの基本的固有振動 数は $6,500 \mathrm{rpm}$ よりも大きくすることができる.これに よって, 乗用車のプロペラシャフトを 1 本の部品からな る構造にすることができる、複合材プロペラシャフトは 他にも重量軽減や騒音や振動の軽減という利点がある.

産業用ロボットは人間による污染を防ぐためにクリー ンルームの環境で盛んに使用されはじめている. 液晶パ ネルのサイズの増大に伴い, ペイロードが増加し, ロボ ットの剛性が要求されるようになった。 それゆえに, ス リムで剛性の高いエンドエフェクタの設計と製作が重要 になった.エンドエフェクタの変形を減少させるために 液晶パネルのガラス板を取り扱う軽量なロボットハンド 用エンドエフエクタが CF/エポキシとハニカムのサン ドイッチ構造によって設計され, 製作された（図 10 参 照).ロボット用複合材エンドエフェクタの静的な変形や 固有振動数, 減衰などの静的・動的特性はアルミニウム 合金製の競合製品と比較して優れた特性を示した。

熱硬化性樹脂を日材とする複合材料の成形プロセスは 複数相の化学反応だけでなく熱と質量の物理的な輸送も 伴う。これらは樹脂の粘性に依存している. 熱硬化性樹 脂の化学反応は複雑なモノマー同士の架橋による発熱反 応である. 複合材製品は硬化過程の温度勾配や不均一な 硬化度によって引き起こされる熱残留応力によって変形 したり, 权じれたりする。それゆえに, 複合材製品の品 


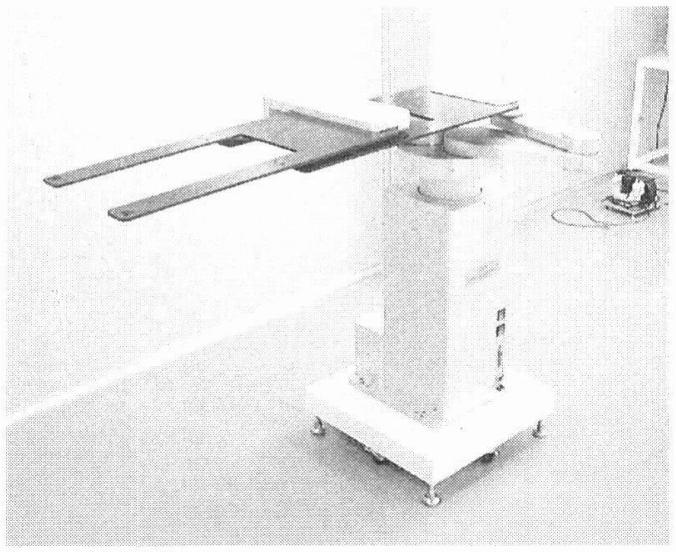

図 10 大型液晶パネル組み立て用ロボットの複合 材製エンドエフェクタ

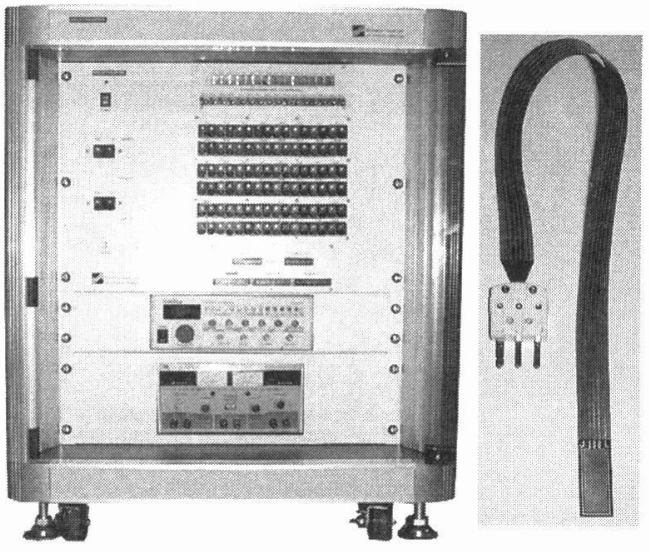

図 $1116 \mathrm{ch}$ オンライン成形誘電センサーとその システム

質向上のために硬化作業のオンライン測定や制御は重要 である。あるいは成形中の周囲温度や圧力のオンライン モニタリングによって短時間に効率的に信頼性の高い複 合材製品が製造できる。新規に開発した16チャンネル の埋め込み $\mathrm{AC}$ ブリッジタイプ回路とインターデジタル 誘電センサーによって, 以前のバージョンよりもさらに 制度良く便利なシステムとなっている (図 11 参照).

\section{4. 複合材料研究室}

複合材料研究室（http:// composite.kaist.ac.kr，Soon Hyung Hong 教授) では, 金属基複合材料とナノ複合材 の製造プロセスと特性評価が行われている.

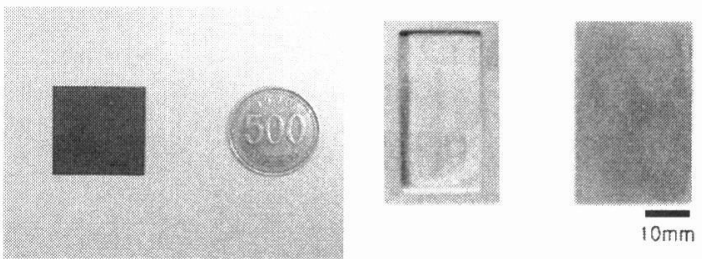

図 $12 \mathrm{SiC}$ アルミ複合材製放熱器とマイクロプロ セッサ

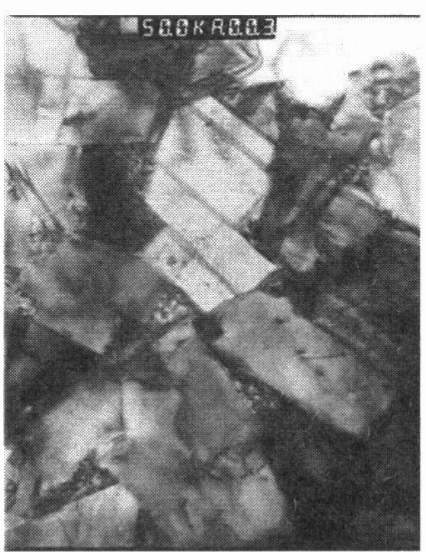

図 13 ナノ結晶性 WC-10 Co 複合材の TEM 写真

金属基複合材料の構造適用に関連して, ウイスカー強 化複合材料の荷重伝達メ力ニズムが解析され，最近は一 般化されたシェアラグモデルが提案された．提案された 理論モデルに基づいて金属基複合材料の高温環境下のク リープ挙動をさらに正確に解析することができる。金属 基複合材料の機能材料としての適用に関しては, 高体積 含有率 $\mathrm{SiC}$ 粒子強化アルミニウム合金の製造のための 高圧溶浸鋳造プロセスが開発された。高体積含有率 $\mathrm{SiC}$ 粒子強化アルミニウム合金複合材料は熱膨張係数が 6.5 $\mathrm{ppm} / \mathrm{K}$ であり, 熱伝導率が $150 \mathrm{~J} / \mathrm{mK}$ である。これは熱 伝導率に関してはセラミック部材より優れており，熱膨 張に関しては金属よりも優れている (図 12 参照).

ナノ複合材料に関しては,ナノ結晶性 $\mathrm{WC} / \mathrm{C}$ 複合材料 が工具材料として，W/Cuナノ複合材料がヒートシンク として検討されている。ナノ結晶性 WC/C 複合材料はス プレー転換プロセスによって準備され，優れた硬さを示 している。これは従来の WC/Co 材のほぼ2 倍である.焼 結 $\mathrm{W} / \mathrm{Cu}$ ナノ複合材料は従来の混合材入りの $\mathrm{W} / \mathrm{Cu}$ 複 合材と比較して, 高い熱伝導率を示している（図 13 参 照). 